\title{
EVALUATION OF TRACTOR DIESEL ENGINE PERFORMANCE USING BIODIESEL FROM THREE DIFFERENT INDIVIDUAL SOURCES
}

\author{
A. E. Gomaa', H. H. Mohamed ${ }^{2}$, A. A. El Gwady ${ }^{3}$ and M. D. Al-Aseebee
}

\begin{abstract}
Biodiesel was prepared from three different individual sources: waste frying oil, palm oil, and castor oil; to compare their performance versus conventional diesel and with respect to each other on the performance of a KUBOTA $67 \mathrm{~kW}$ tractor diesel engine. All tested fuels were purely used without any blending. Tractor engine was tested through a P.T.O. hydraulic brake dynamometer at the tractors testing station - Agricultural Engineering Research Institute. Engine performance characteristics and main indicators were determined: P.T.O. torque and power, engine brake power (BP), brake thermal efficiency (BTE), brake specific fuel consumption (BSFC), brake mean effective pressure (BMEP), and air fuel ratio (AFR). The highest performance was achieved by the conventional diesel. The performance of all tested biodiesels were close to each other; and no clear preference of any specific biodiesel could be considered. Their tested properties were also very close. So, the decision of selecting a specific biodiesel (prepared from a specific source) depends mainly on its availability and economical feasibility wherever is used.
\end{abstract}

Keywords: Biodiesel, I.C. engines, Transesterification, Vegetable fuels.

\section{INTRODUCTION}

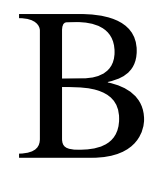
iodiesel is a clean renewable fuel made from natural sources such as new or used vegetable oils and animal fats. The biodiesel is quite similar to conventional diesel in its main characteristics. Biodiesel contains no petroleum products, but it is compatible with conventional diesel and can be blended in any proportion with mineral diesel to create a stable biodiesel blend.

1- Prof. Emeritus of Ag. Eng.- Fac. of Ag. Saba Basha, Univ. of Alex. Egypt.

2- Assist. Prof. of Ag. Eng.- Fac. of Ag. Saba Basha, Univ. of Alex. Egypt.

3- Senior Researcher-Agricultural Engineering, Research Institute, Egypt.

4- M.Sc. student, Fac. of Ag. Saba Basha, Univ. of Alex. Egypt. - Comer from Ministry of Agriculture, Iraq. 
Shahid and Jamal (2011) reported that transesterification is regarded as the best method to prepare biodiesel, among other approaches due to its low cost and simplicity which consists of a number of reversible reactions. In these reactions, the triglycerides are converted step wise to glycerol which sinks to the bottom and biodiesel which floats on top and can be separated. In this reaction, methanol and ethanol are the two main light alcohols used for transesterification process due to their relatively low cost.

Barsin and Humke (1981) reported that when diesel engine was run with vegetable oil as fuel, produced equivalent power to that of the diesel fuel because fuel mass flow energy delivery increased due to higher density and viscosity of vegetable oil. It also increased fuel flow by reducing internal pump leakage. The lower mass-based heating values of vegetable oils required larger mass fuel flow to maintain constant energy input to the engine. Reed et al. (1991) converted waste cooking oils to methyl and ethyl esters and tested pure biodiesel and a 30\% blend in diesel fuel in a diesel-powered bus on a chassis dynamometer. No significant difference in power and performance was observed except for a visible reduction of smoke on acceleration with the esters of the used oil. They also found that the smoke opacity was reduced to $60 \%$ of the diesel value by the $30 \%$ blend and to $26 \%$ of the diesel value by the pure ester. Baiju et al. (2009) found that the brake specific fuel consumption BSFC increased when using biodiesel as compared to diesel for the same power output. This was because the heat value of biodiesel is less than this of the diesel. Krawczyk (1996) reported that increasing the use of petroleum will intensify local air pollution and magnify the global warming problems caused by carbon dioxide. Biodiesel has the potential to reduce the level of pollutants and the level of potential for probable carcinogens. This research was carried out in order to: 1) evaluate the tractor diesel engine performance with biodiesel from waste frying oil, palm oil and castor oil, 2) compare the performance between the above mentioned biodiesel fuels and diesel fuel, and 3) determine the best operating conditions to maximize tractor engine performance using biodiesel fuels. 


\section{MATERIALS AND METHOD}

In the laboratory of Soil and Agricultural Engineering dept.-Faculty of Agriculture (Saba Basha); three different biodiesels were prepared from three different individual sources: waste frying oil, palm oil, and castor oil, by transesterification process. They were tested as alternative fuels for tractor engine at the Testing and Research Station for Tractors and Agricultural Machinery, Alexandria.

Biodiesels operational properties were measured at Misr Petroleum Co. laboratory. The results are summarized in Table (1):

\section{Table (1): Results of all tested biofuels operational properties.}

\begin{tabular}{l|c|c|c}
\hline \multicolumn{1}{c|}{ Property } & FO & PaO & CaO \\
\hline Flash point ${ }^{\circ} \mathrm{C}$ & 140 & 185 & 170 \\
\hline Pour point ${ }^{\circ} \mathrm{C}$ & -6 & 12 & 12 \\
\hline Calorific value $(\mathrm{MJ} / \mathrm{kg})$ & 42.3 & 42.3 & 42.5 \\
\hline Ash content $(\%$ by weight) & Nil & Nil & Nil \\
\hline
\end{tabular}

A hydraulic brake stationary dynamometer $90 \mathrm{~kW}$ was hooked to $67 \mathrm{~kW}$ tractor to measure both torque and rpm exerted on the tractor power take off shaft (PTO) at different loads when operating the tractor engine on biodiesel as shown in Fig. (1).

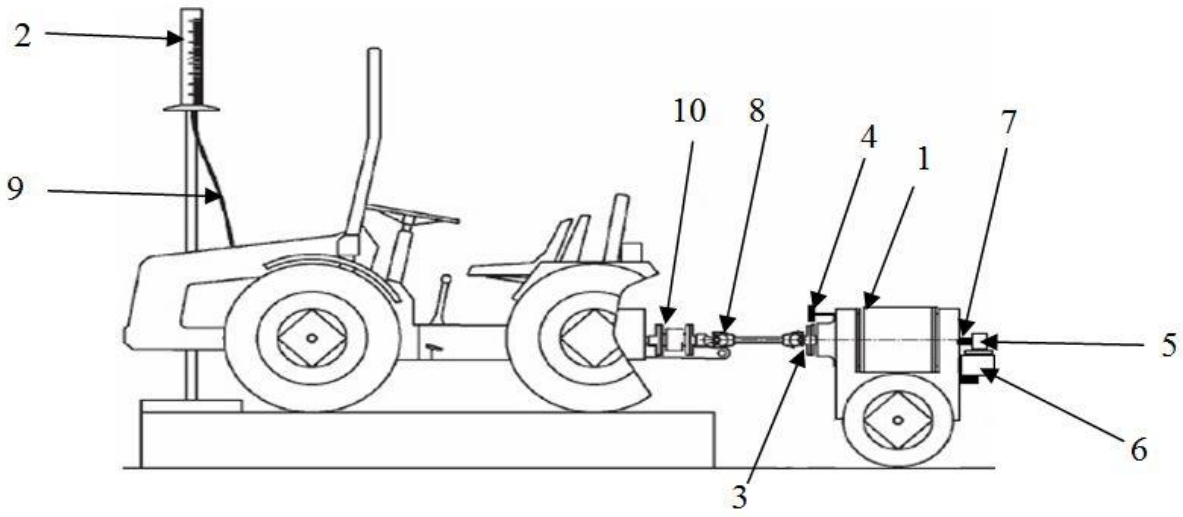

1-Hydraulic brake dynamometer

3-RPM toothed gear

5-Torque arm lever

7-Rotating drum shaft

9-Hose to injection pump
2-Fuel graduated cylinder

4-RPM magnetic core

6-Strain gage load cell

8-Tractor P.T.O shaft

10-Coupling connection

Fig.(1): Schematic view of the engine test arrangement 
Technical specifications of tractor and hydraulic brake stationary dynamometer are presented in Table (2):

Table (2) Technical specifications of the tractor

\begin{tabular}{|l|l|}
\hline Model & Kubota $_{1}-100 \mathrm{~S}-\mathrm{DT}$ \\
\hline Type of engine & $\begin{array}{l}\text { Four stroke, indirect injection ,Turbocharged , } \\
\text { liquid cooled diesel }\end{array}$ \\
\hline Engine power, $\mathrm{kW}(\mathrm{HP})$ & $73.6(100)$ \\
\hline Rated Engine speed , rpm & 2600 \\
\hline Compression ratio & $21.8: 1$ \\
\hline Number of cylinders & 4 -cylinder \\
\hline Bore $*$ stroke, mm & $100 \times 120 \mathrm{~mm}$ \\
\hline Technical specifications of the hooked hydraulic brake stationary dynamometer \\
\hline Model & NEB600 \\
\hline Serial number & CD6190C5 \\
\hline \multirow{2}{*}{ Range } & $300 \mathrm{~kW}$ at $540 \mathrm{rpm}$ \\
\cline { 2 - 2 } & $600 \mathrm{~kW}$ at $1000 \mathrm{rpm}$ \\
\hline Capacity of torque & $4338 \mathrm{Nm}$ \\
\hline
\end{tabular}

A daytronic data PAC model 10k4 was used to record data measured by the torque cell sensor and the magnetic pick-up frequency sensor as shown in Fig (2). These two sensors are engaged to the AW dynamometer; The sensing torque cell has a full whinstone bridge of strain gage for recording the torque applied to P.T.O. during test; while a magnetic pick-up frequency sensor consists of a toothed wheel, (60 teeth), coil, and iron core was used to record the P.T.O shaft rpm, as the toothed wheel rotates, the magnetic field of the magnetized source is

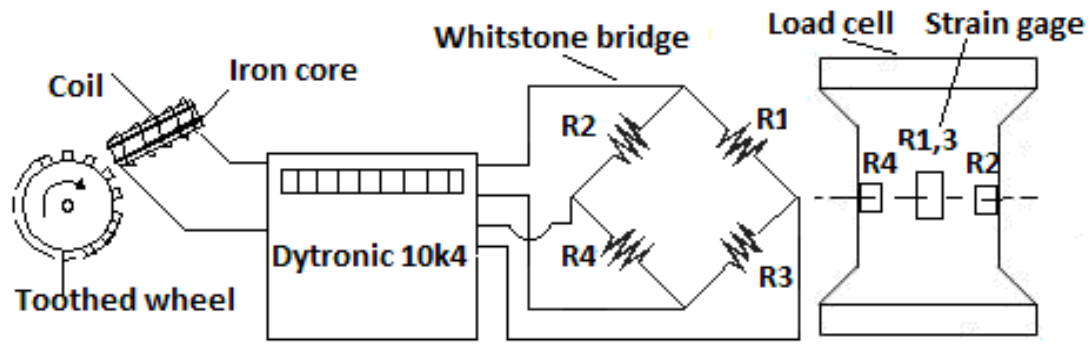

detected, and displayed as RPM.

Fig. (2) Dytronic and AW sensors wiring diagram 
Prior to the measurements, the tractor was left running for $1 \mathrm{hr}$ to warm up all parts and liquids to the working temperature. At the same time and before each measurement for each fuel type, the whole system was running for $10 \mathrm{~min}$ at full throttle. Every measurement of torque and rotational frequency of PTO was recorded at tractor full throttle. During the experiments, the time required for consuming $100 \mathrm{~cm}^{3}$ of each fuel was also recorded; the first measurement was carried out at load set zero, then at standard PTO speed $540 \mathrm{rpm}$, and at maximum load. For every subsequent measurement, the load on the AW hydraulic brake was increased in order to decrease the rotational frequency of the PTO. All engine settings (throttle, cooling...) remained unchanged during the whole experiment for each particular fuel type. Two test run measurements were performed for each fuel type. When testing a new fuel it was made sure that, the previously tested fuel was completely removed from the pipelines and filter system by running the engine on the new fuel for $10 \mathrm{~min}$ at full throttle before doing any measurements.

\section{Calculation of performance indicators}

\section{PTO Torque and Power:}

Both torque in N.m and rotational speed in rpm, were measured in the lab using the AW hydraulic brake stationary dynamometer for tractor power take off shaft calculation, , at different PTO speed, using the following equation.

$$
P=2 \pi n \tau / c \quad k W \ldots \ldots . . .(1)
$$

Where:

$\begin{array}{lll}\text { P } & \text { Power take off shaft P.T.O } & \mathrm{kW} \\ \mathrm{n} & \text { Measured rotational speed for P.T.O } & \mathrm{rpm} \\ \tau & \text { Measured torque for P.T.O in } & \text { N.m } \\ \mathrm{c} & \text { constant, equals } 60000 & \end{array}$

\section{Engine Brake Power BP:}

According to KUBOTA tractor technical data, PTO power is $88.9 \%$ of the engine BP. For a used tractor the present work considered the PTO power as $88 \%$ of the engine $\mathrm{BP}$; and the ratio between engine and PTO shaft speeds (rpm) is $(2205 / 540)$ or 4.0833:1. 


$$
B P=\frac{P T O \text { power }}{0.88} \quad k W \ldots \ldots . . .
$$

\section{Fuel Consumption:}

A volume of fuel consumed $\left(\mathrm{cm}^{3}\right)$ was measured during each test run at no load, at standard PTO speed, and at full load. Consumption time for each test was also measured and the volumetric fuel consumption rate was calculated for each load as follows:

$$
V F C=(V * 3600) /(t * 1000)
$$

Where:

$\mathrm{V}$ : volume of consumed fuel in glass bulb, $\mathrm{cm}^{3}$

$\mathrm{t}$ :Time of running the test, $\mathrm{s}$

VFC: Volumetric fuel consumption rate, $1 . \mathrm{h}^{-1}$

\section{Brake thermal efficiency BTE:}

This parameter is obtained by dividing the effective power from engine to the amount of energy given to the engine.

$$
\eta=\frac{B P \times 3600}{V F C \times \rho_{F} \times H V}
$$

Where:

$\mathrm{BP}=$ Brake power, $\mathrm{kW}$

$\rho_{f}=$ density of the tested fuel, $\mathrm{kg} / \mathrm{l}$

$\mathrm{VFC}=$ Fuel consumption rate, $\mathrm{l} / \mathrm{h}$

$\mathrm{HV}=$ heat value of the tested fuel, $\mathrm{kJ} / \mathrm{kg}$.

\section{Brake Specific Fuel Consumption BSFC:}

BSFC is the quotient of fuel consumption rate $(1 / h)$ and the corresponding $\mathrm{BP}(\mathrm{kW})$ at the same loading conditions represented by the different levels of engine speed (rpm) starting from 408.33 to 2858.31(100 to 700 PTO rpm).

$$
B S F C=\frac{V F C}{B P} \quad l /(k W . h)
$$

\section{Brake Mean Effective Pressure BMEP:}

BMEP is a useful concept which can be obtained if the standard expression for computing indicated power IP is applied to brake power 
BP instead of IP, and the mean effective pressure is designated as BMEP. So BP in $\mathrm{kW}$ can be expressed as follows:

$$
B P=\frac{B M E P \times L \times A \times n \times N}{60 \times 2} \quad k W
$$

Where, BMEP: Brake Mean Effective Pressure, kPa.

L: Piston displacement, $\mathrm{m}$.

A: Piston cross-sectional area, $\mathrm{m}^{2}$.

$\mathrm{N}$ : Engine rotation speed, rpm.

$\mathrm{n}$ : Number of engine cylinders,

2: Constant referring 4 - stroke engine.

60: Constant for unit conversion, s.

BMEP gives an indication of the engine state at a certain loading level, which expresses the output per piston displacement. As BMEP increases, the engine develops greater power, where its BMEP changes in direct proportion with load as follows:

$$
B M E P=\frac{B P \times 120}{L \times A \times n \times N}
$$

\section{Air Fuel Ratio AFR:}

AFR is defined as the ratio of the mass of air to the mass of fuel in the combustion process. Hence, the following steps had to be determined:

1- Air mass flow rate.

2- Fuel mass flow rate from the system measurement equipment.

3 - The quotient of step 1 by step 2 is the AFR.

Volumetric efficiency $\eta_{\mathrm{v}}$ is defined as the ratio of air volume input / minute, $v_{a}$, measured at the inlet air conditions, to the number of cylinder swept volume / minute, $\mathrm{v}_{\mathrm{s}}$ :

$$
\eta_{v}=\frac{v_{a}}{v_{s}}
$$


The $\eta_{\mathrm{v}}$ of the KUBOTA tractor supercharged engine, could be determined at any operating point (engine speed) As later shown and explained from Fig.(15), from which the actual air volume flow rate, va $\left(\mathrm{m}^{3} /(\mathrm{min} \cdot \mathrm{cyl})\right)$ could also be determined per one single cylinder from equation (8) as follows:

$$
v_{a}=\eta_{v} \times v_{s}
$$

Where,

$$
\begin{gathered}
v_{s}=\left(\frac{\text { number of suction strokes }}{\mathrm{min} \cdot \mathrm{cyl}}\right) \times \text { piston surface area } \times \text { displacement } \\
v_{s}=\left(\frac{\text { Engine revs. }}{\min \cdot 2 \cdot \mathrm{cyl}}\right) \times \frac{\mathrm{cm}^{2} \cdot \mathrm{cm}}{10^{6}}
\end{gathered}
$$$$
\text { Air mass flow rate }\left(\frac{k g_{m a}}{\min \cdot c y l}\right)=v_{a}\left(\frac{m^{3}}{\min \cdot c y l}\right) \times \text { air density }\left(\frac{k g_{m a}}{m^{3}}\right) .
$$

An average air density of $1.204\left(\mathrm{kgm}_{\mathrm{m}} / \mathrm{m}^{3}\right)$ is considered. Table ( 1$)$ showed the measured density data for all tested fuels in $\left(\mathrm{kg}_{\mathrm{m}} / \mathrm{l}\right)$. The measured fuel consumption rate for all tested fuels was divided by 4 cylinders to determine the fuel consumption rate $\mathrm{v}_{\mathrm{f}}$ per one single cylinder in $(1 / \mathrm{min}$.cyl). Then the mass flow rate of all tested fuels is determined as follows:

$$
\text { Fuel mass flow rate }\left(\frac{k g_{m f}}{\min \cdot c y l}\right)=v_{f}\left(\frac{l}{\min \cdot c y l}\right) \times \text { fuel density }\left(\frac{k g_{m f}}{l}\right) \ldots
$$

$$
\mathrm{AFR}=\text { equ. (10)/equ. (11) }
$$

\section{RESULTS AND DISCUSSION}

\section{Engine performance characteristics:}

\section{PTO Torque and Power}

For all tested fuels, the measured variation of PTO torque with the variable PTO speed due to loading effect is shown by Fig.(3), their corresponding best fit relationships and equations are shown in Fig.(4); then for each PTO torque recorded value and the corresponding rpm coordinate of all fuels in Fig.(3), a 
PTO power value was calculated to locate the relationships between their PTO power and PTO speed as illustrated by Fig.(5). Torque values in Fig.(3), were minimum at no load conditions (max. speed), then increased for all tested fuels with the PTO or engine speed decrease, until 500-540 PTO rpm (around 2000 engine rpm), then they started to slightly decrease with load increase towards maximum (min. speed). The highest torque values, fluctuated within 900-1000 Nm, (0.9-1.0 kJ), were of conventional diesel, followed by a bundle of the three biodiesels fluctuated around $800-900 \mathrm{Nm}$ for all engine operation conditions.

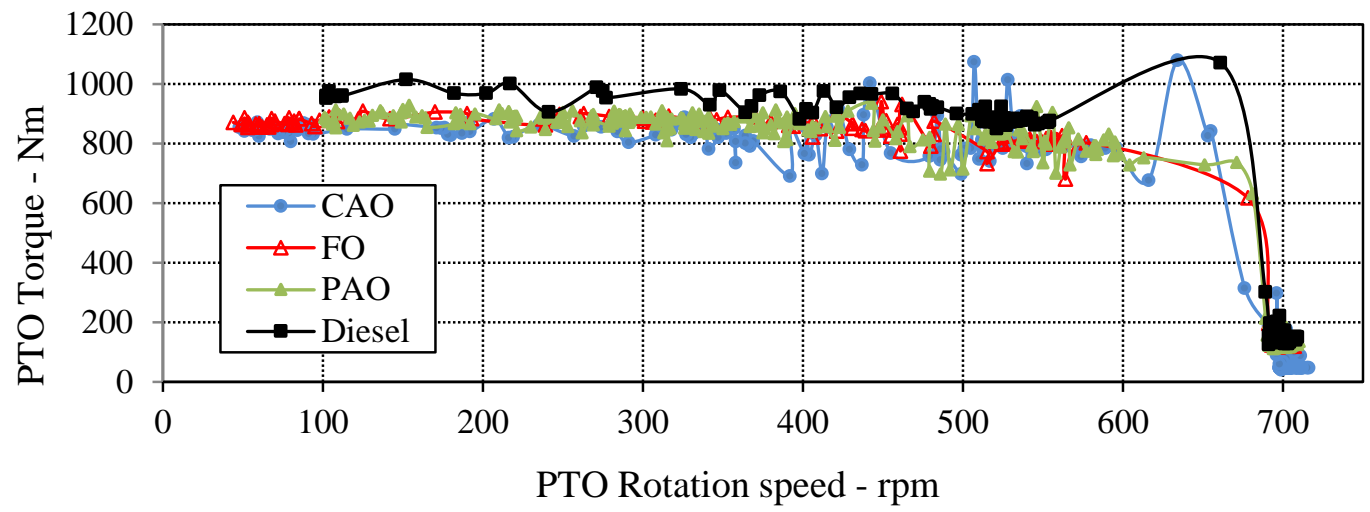

Fig.(3):Measured PTO Torque output versus its rotation speed

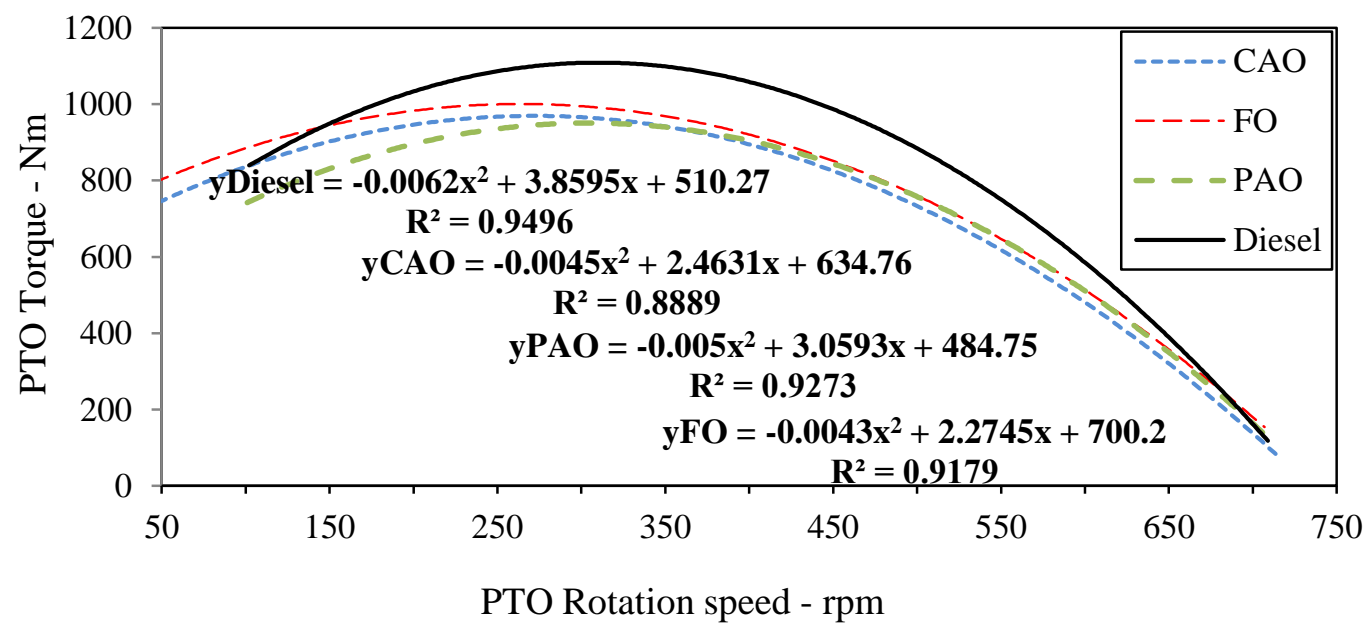

Fig.(4): Best fit of PTO Torque output versus its rotation speed 


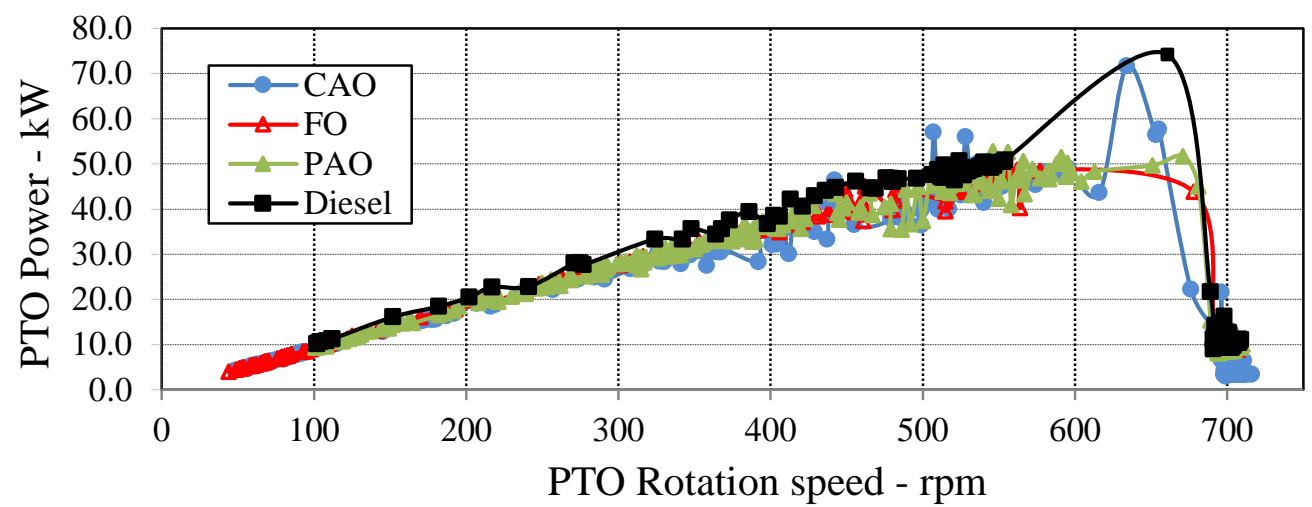

Fig.(5): Calculated PTO Power output versus its rotation speed

\section{Engine Brake Power BP:}

Best fit equations of Fig.(4), were used to determine values of PTO torque at each $100 \mathrm{rpm}$ interval of PTO speed, starting from 100 to $700 \mathrm{rpm}$ to express the whole range of dynamometer test; then corresponding PTO power values were similarly calculated as mentioned above, from which brake power values were determined at their corresponding engine rpm, then presented graphically in Fig.(6), based on power transmission efficiency of $88 \%$ and speed reduction ratio of 4.083:1 between the tractor engine and PTO shaft. For all tested fuels, BP increases with the increase of engine speed due to mass increase of burning fuel; the highest power values were obtained at 1900-2000 rpm engine speed. Conventional diesel fuel was of the highest power $(53 \mathrm{~kW})$; while power levels obtained from the tested biodiesel fuels were close to each other (around $45 \mathrm{~kW}$ ). The higher values of viscosity and density of biodiesel fuels can partially explain this result.

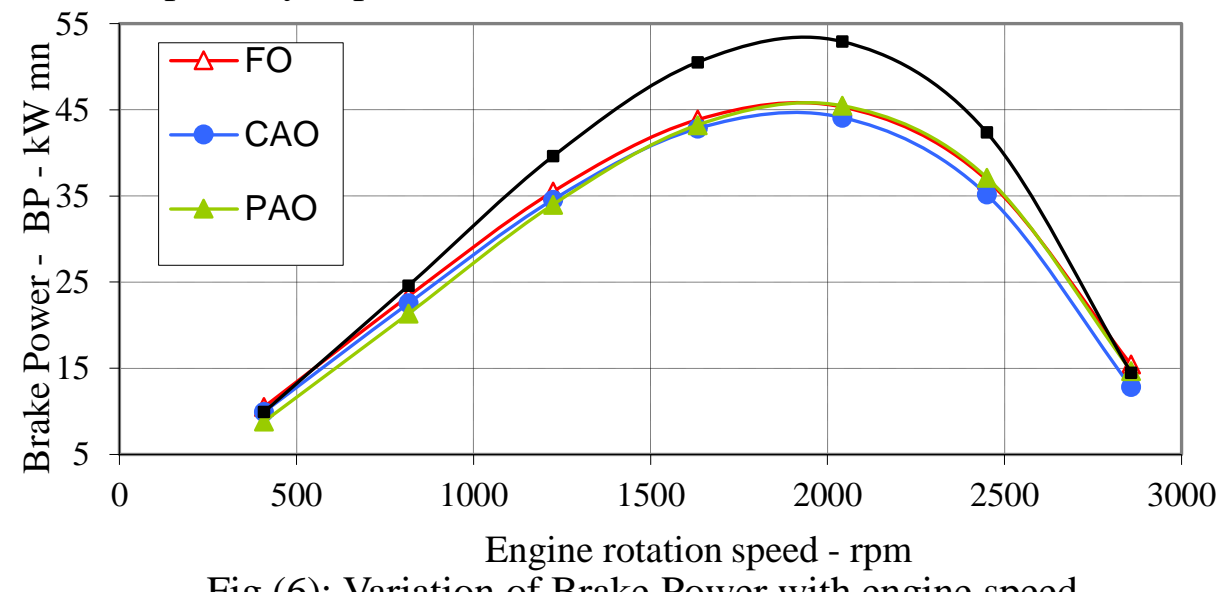

Fig.(6): Variation of Brake Power with engine speed. 
Buyukkaya (2010) pointed to the higher viscosity of biodiesel fuels, which may affect the engine brake effective power and engine torque especially at full-load conditions, increases the fuel momentum and consequently penetration depth in-cylinder. On the other hand, the higher viscosity and surface tension of biodiesel fuels prevent their sufficient breaking during injection process.

\section{Brake thermal efficiency BTE:}

BTE is a parameter that determines the transformation of heat energy to useful work. Energy that is obtained from the combustion in internal combustion engines does not convert completely into useful work due to heat losses caused by friction, cooling and exhaust. Further, biodiesel fuels have lower heat value on weight basis because of presence of substantial amount of oxygen in the fuel but at the same time have a higher specific gravity as compared to conventional Diesel. Fig.(7) shows the variation of brake thermal efficiency with engine speed for the tested fuels; the highest BTE values obtained at 1600 to $2000 \mathrm{rpm}$ engine speed (almost 400 to $500 \mathrm{rpm}$ PTO shaft speed) are of Diesel (27.9 to $28.2 \%$ ), which heat value was about $45 \mathrm{MJ} / \mathrm{kg}$, followed by PAO, CAO, and FO biodiesel fuels at the same range of speed, which their heat values aren't so different: $42.3,42.5$, and $42.3 \mathrm{MJ} / \mathrm{kg}$ resp. but their BTE vary from 26.776 to $26.769 \%, 23.829$ to $23.626 \%$, and 23.598 to $22.789 \%$ resp. Behcet (2011) mentioned that the ignition delay becomes longer due to high viscosity and density of the biodiesel fuels, resulting in poor atomization. Longer ignition delay results in incomplete combustion and thus lower thermal efficiency due to higher exhausts gas temperatures.

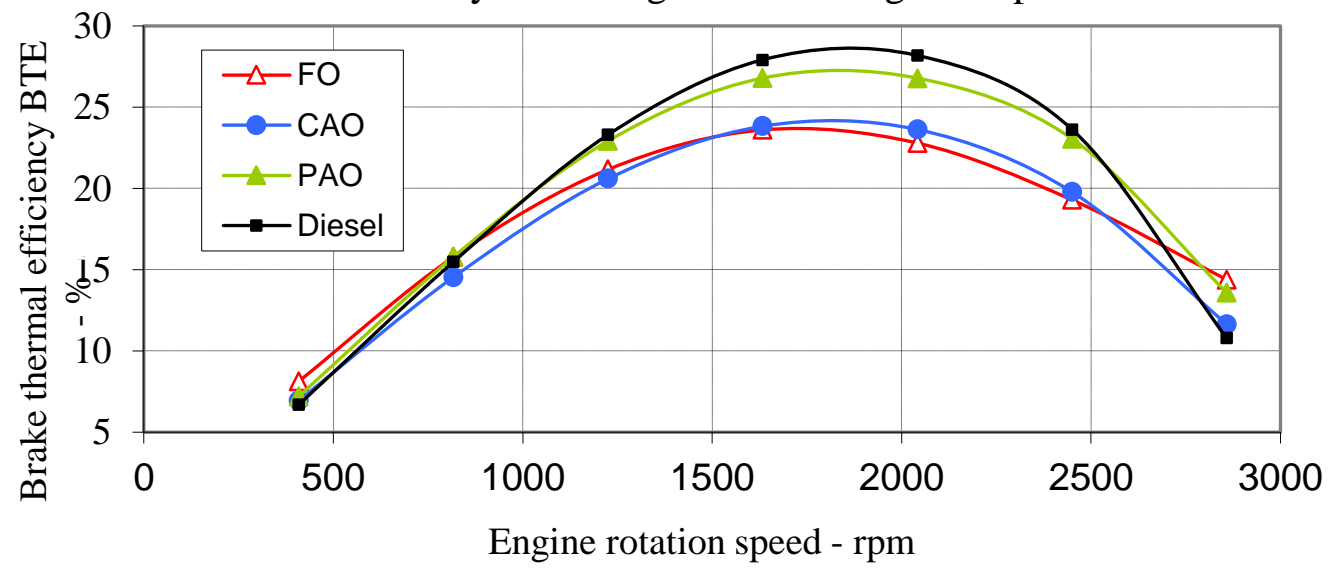

Fig.(7): Variation of Brake Therm. Eff. with engine speed. 
The main reasons for lower thermal efficiency are the lower effective power, higher fuel consumption and lower calorific values of biodiesel fuels in comparison to conventional Diesel fuel.

Some researchers have reported higher brake thermal efficiency for engines fueled with biodiesel than that of Diesel. A possible explanation for this increase was attributed to the atomization of these biodiesel fuels during injection and/or with their stability during storage, pumping and injection. Another possible reason may be the reduction in friction loss associated with their higher lubricity. However, the possible reason for poor thermal performance of biodiesel fuels compared to base line diesel operation could be attributed as mentioned above, to their higher viscosity. Fig.(8) shows the proportional relationship between BTE and Brake Power.

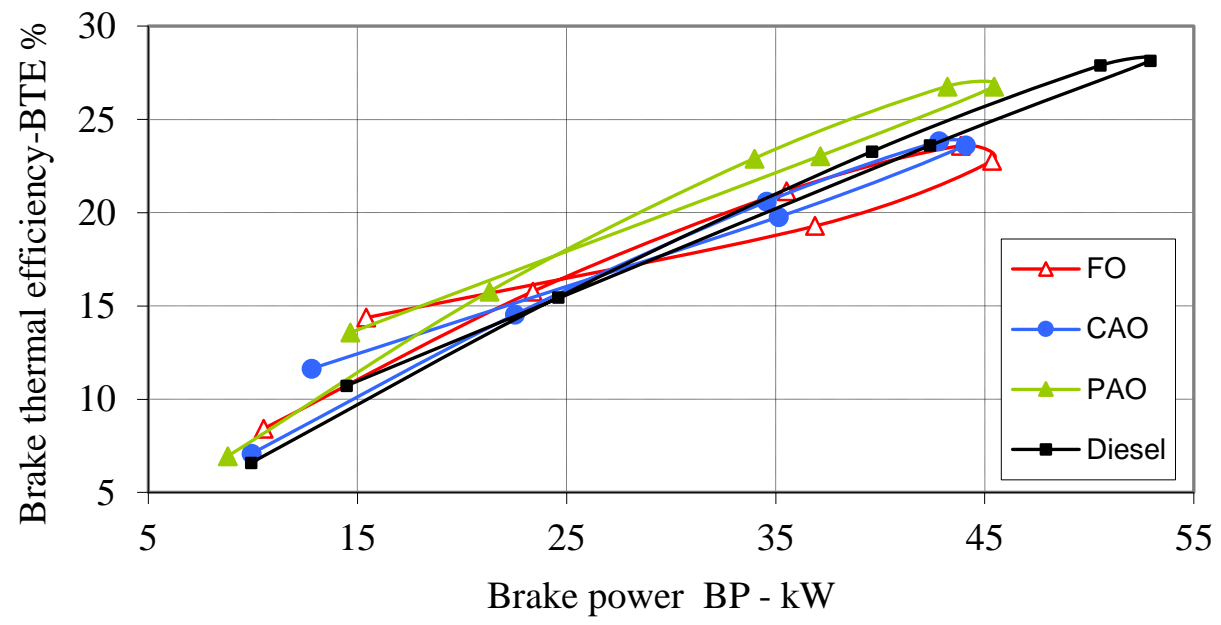

Fig.(8) Variation of Brake Therm. Eff. with Brake Power

However, the present study results of BP and BTE are corroborated by the results by Shehata (2013); who referred the highest BP and BTE obtained values of Diesel fuel to: 1- The highest heating value caused by lowest oxygen content in molecules, 2- The lowest viscosity which enhances atomization process and combustion characteristics, and 3- The lowest heat losses in exhaust gases. High viscosity decreases combustion quality due to the increase in fuel mean droplet diameter leading to poor atomization process. On the other hand, oxygen content in biodiesel molecules improves 
combustion quality and decreases heat of combustion. So, the drop in BP and BTE with biodiesel fuels prove that their poor combustion characteristics due to high viscosity and poor volatility overcomes the effect of excess oxygen content in biodiesel molecules. The mass flow rates of biodiesel fuels are higher than diesel but the heat value of diesel fuel is higher than biodiesel fuels. So, the effect of heat value magnitude of diesel fuel overcomes the effect of biodiesel fuels mass flow rate magnitude and the net result is decreasing BP of biodiesel fuels than diesel fuel.

\section{Brake Specific Fuel Consumption BSFC:}

Fig.(9) illustrates the variation of BSFC with engine speed, and Fig.(10) shows its best fit relationships and their equations describing the variation of BSFC with engine speed for all tested fuels. Fig.(9) shows that the brake specific fuel consumption trend for diesel and the three biodiesel fuels are similar in nature. The results also showed that the BSFC of the biodiesel fuels are higher than that of conventional diesel. This behavior is attributed to their noticeably lower heating value per unit mass, than that of the diesel fuel. Therefore, the amount of fuel introduced into the engine cylinder for a desired fuel energy input has to be greater with the biodiesel. The decrease in BSFC could be explained by the fact that, as the engine load increases, the rate of increasing brake power is much more than that of the increased fuel consumption (as shown by Fig.(11)), owing to a rise in the combustion temperature (indicated by cylinder pressure) with load. The conversion of heat energy to mechanical work increases with rise in combustion temperature which leads to decrease the BSFC with respect to the related load, but this engine behavior is retreated at the final engine working points, where the produced BP is gradually reduced until vanishing due to the ascending braking effect exerted from the dynamometer on the PTO shaft to reach maximum loading conditions. However, the lowest BSFC values have been obtained for diesel fuel at medium engine speeds. At the highest engine speed, the BSFC values of biodiesel fuels were lower than that of diesel fuel. The reason for lower fuel consumption for biodiesel fuels may be due to their improved combustion, thanks to their inherently oxygen content, and the efficient combustion time for biodiesel fuels for complete combustion. 


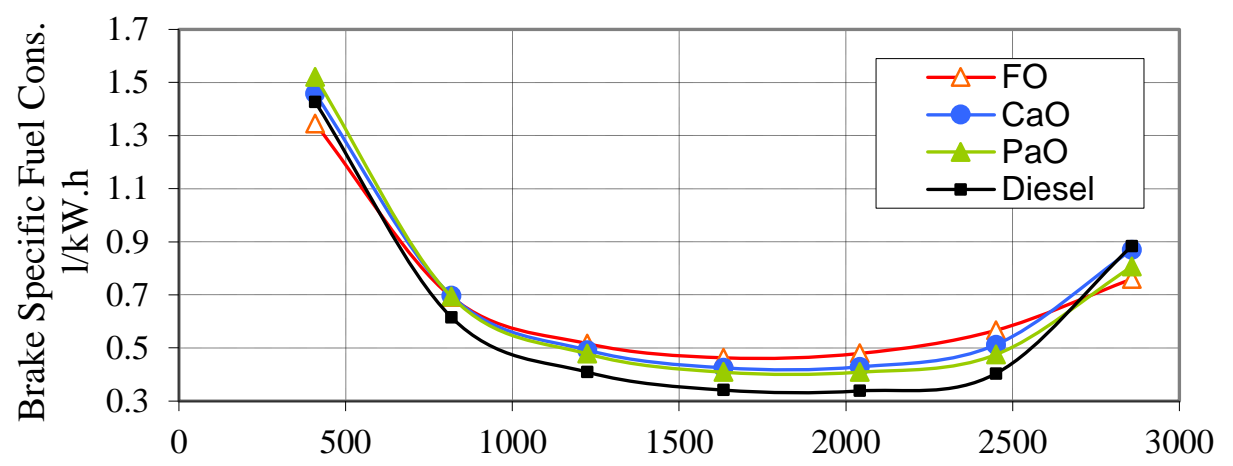

Engine rotation speed - rpm

Fig.(9) Brake Specific Fuel Consumption BSFC variation with engine rotation speed, for all tested fuels.

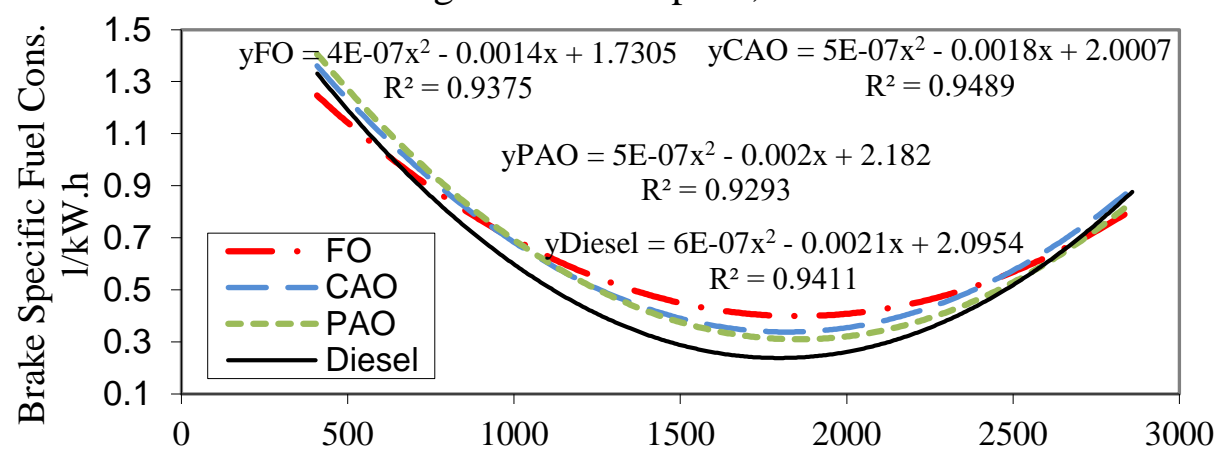

Engine rotation speed - rpm

Fig.(10) Best fit of Brake Specific Fuel Consumption variation with engine rotation speed, for all tested fuels.

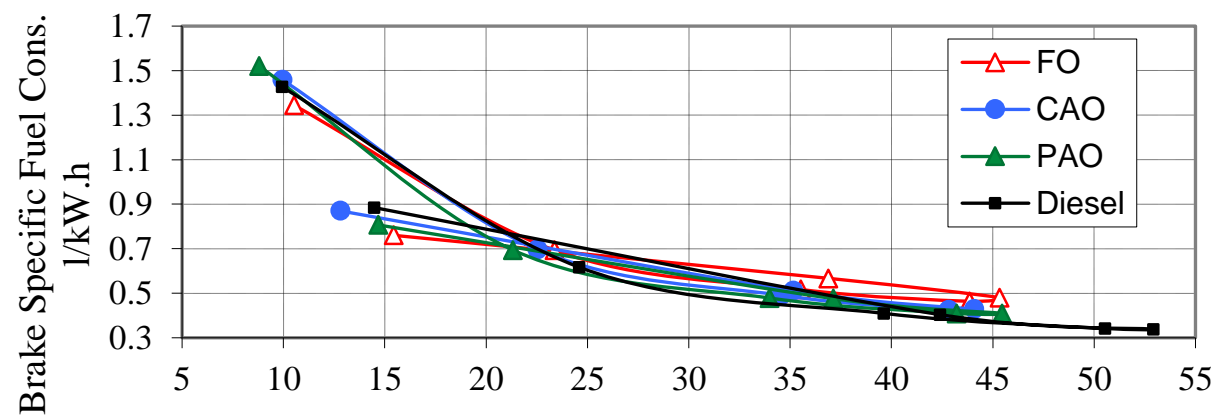

Engine brake power - kW

Fig.(11): Variation of Brake Specific Fuel Cons. BSFC with engine Brake Power BP for all tested fuels.

\section{Brake Mean Effective Pressure BMEP:}

Fig.(12) illustrates the calculated changes in BMEP, for all tested fuels from no load to full load conditions expressed by engine speed. The highest BMEP 
was of the conventional diesel fuel due to high heating value which increased heat release for diesel fuel and consequently increased BP and BMEP; except for maximum load operating point, the BMEP of the frying oil FO biodiesel exceeded which of conventional diesel fuel. For all tested fuels, the peak of both BMEP and torque occurred almost at the same engine speed (1200 rpm) [see Fig.(4) where engine speed $=$ PTO speed * 4.083] which is lower than this of BP peak, then it decreased with engine speed increase towards no load conditions. However when torque fluctuated, BMEP changed proportionately. Since BP is also a function of torque at a constant speed, therefore, changing BMEP is almost similar to BP at the same operating points represented by engine speed as shown in Fig.(13) where, BMEP increased for all fuels with $\mathrm{BP}$ increase to a certain engine speed.

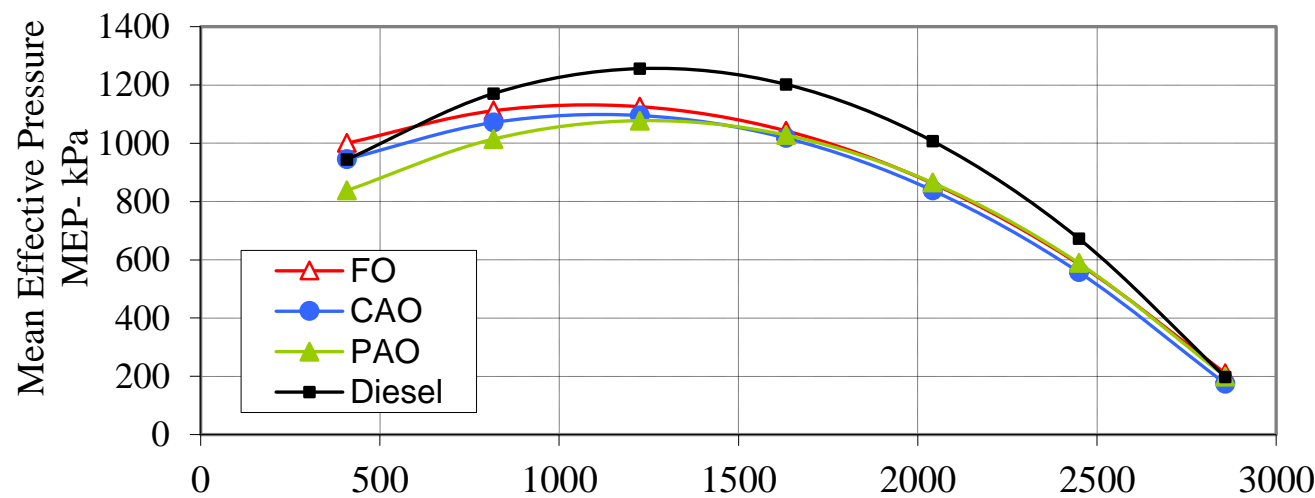

Engine rotation speed - rpm

Fig.(12): Variation of Mean Effective Press. with engine speed

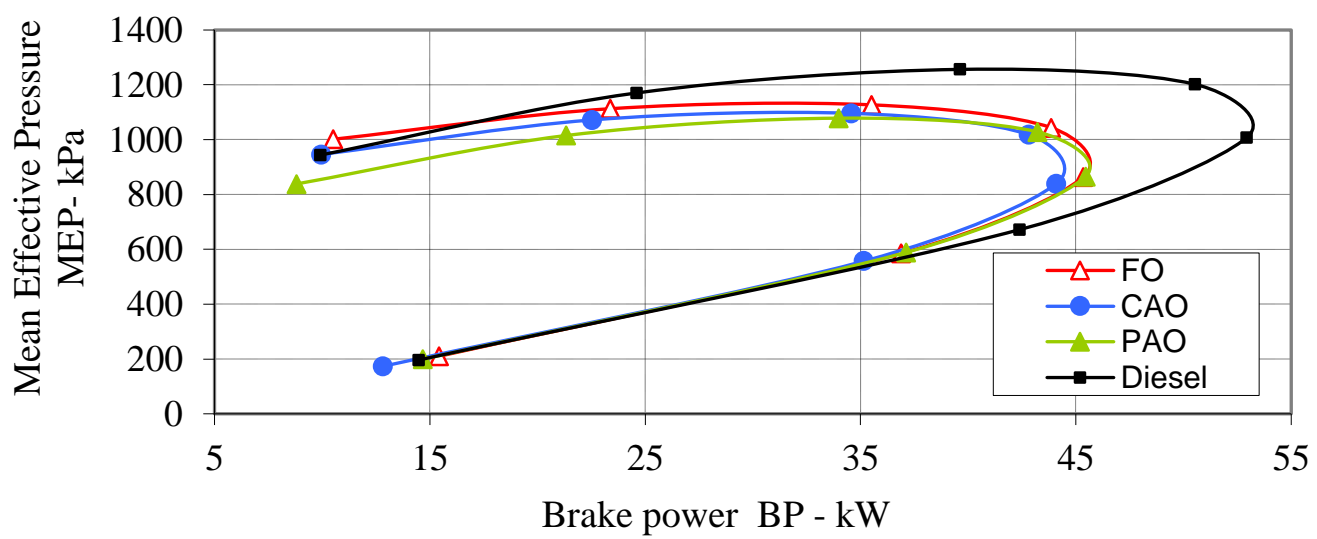

Fig.(13): Variation of Mean Eff. Press. with Brake Power. 
After that, BMEP is retreated at the final engine working points, where the produced BP is gradually reduced until vanishing at lowest engine speed.

\section{Air Fuel Ratio AFR:}

The actual air volume flow rate consumed with all tested fuels, was estimated based on the standard evaluation taken from Gupta (2009), for both of air/fuel ratio AFR, and volumetric efficiency $\eta_{\mathrm{v}}$. The nature of each is explained as follows:

For a given engine speed, the supply of air in the engine is almost constant and does not depend upon the engine load. This engine may be termed a constant air supply engine. With the change in load the quantity of fuel is changed, which alters the AFR. As the load increases, more fuel is used. The overall AFR may vary from 100:1 at no load to 20:1 at full load. On the other hand, this constant air supply at any defined engine speed is completely based on another parameter which is the $\eta_{\mathrm{v}}$.

$\boldsymbol{\eta}_{\mathbf{v}}$ : Is simply the efficiency of the engine cylinders fullness with air. $\eta_{\mathrm{v}}$ is a measure of the effectiveness of an engine process. It is affected by many variables such as compression ratio, valve timing, induction and port design, mixture strength, latent heat of evaporation of the fuel, heating of the induced charge, cylinder pressure, and the atmospheric conditions. The most influencing variable is the induction system components, which directly restrict the amount of air that an engine of given displacement can induct. $\eta_{\mathrm{v}}$ is only used with four- stroke cycle engines which have a distinct induction process. $\eta_{\mathrm{v}}$ of a normally aspirated engine is the ratio of the actual volume flow rate of air entering the engine cylinder $v_{a}$ at the atmospheric pressure and temperature conditions surrounding the engine to the rate at which the volume is displaced by the piston (swept volume) $v_{s}$, while $\eta_{v}$ of a supercharged engine is based on the intake manifold pressure and temperature conditions. Using forced induction, such as supercharging or turbo charging, can easily pushes the $\eta_{\mathrm{v}}$ up to $120 \%$ or more.

The variation of $\eta_{\mathrm{v}}$ with engine speed presented by Gupta (2009) is shown in Fig.(14); this relationship is assumed applicable for KUBOTA tractor supercharged engine utilized in this study, with replacing its engine speed limits (from 0 to $6000 \mathrm{rpm}$ ) on $\mathrm{x}$-axis, by the KUBOTA tractor engine speed range (from 0 to $3000 \mathrm{rpm}$ ). Then, on the basis of the above justification, all vertical coordinates of the original relationship were adapted by increasing them with a minimum amount of $20 \%$, to reach an assumed relevant $\eta_{\mathrm{v}}$ level 
to represent the KUBOTA tractor supercharged engine performance illustrated by Fig.(15). However, the $\eta_{\mathrm{v}}$ is maximum at a certain engine speed and decreases at both higher and lower speeds. Shehata (2013)

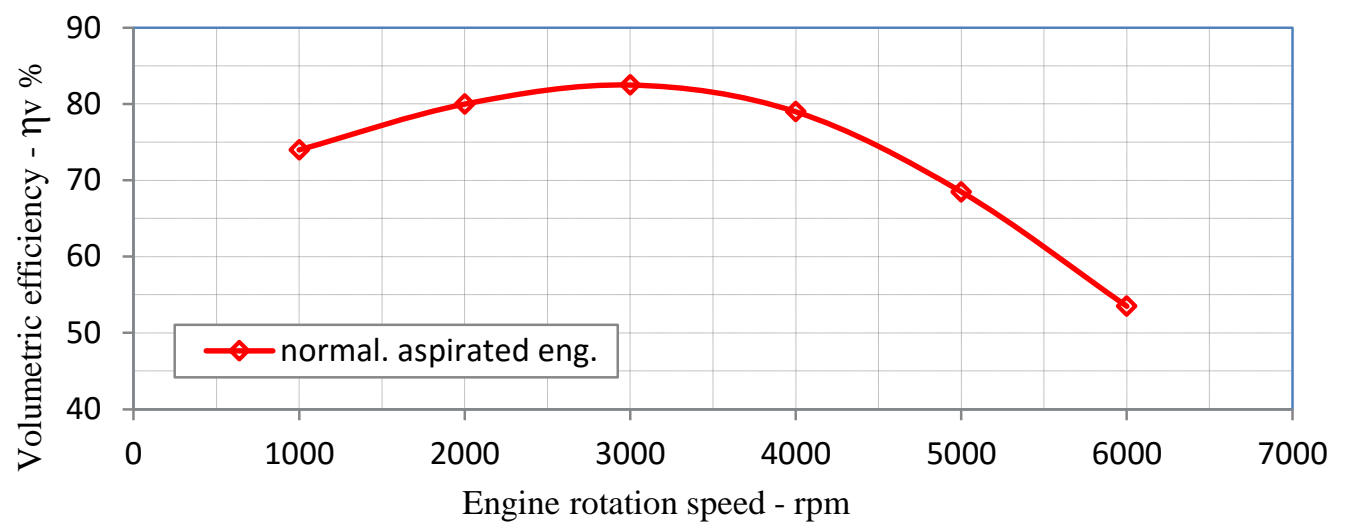

Fig.(14): $\eta_{v}$ as a function of engine speed from Gupta (2009)

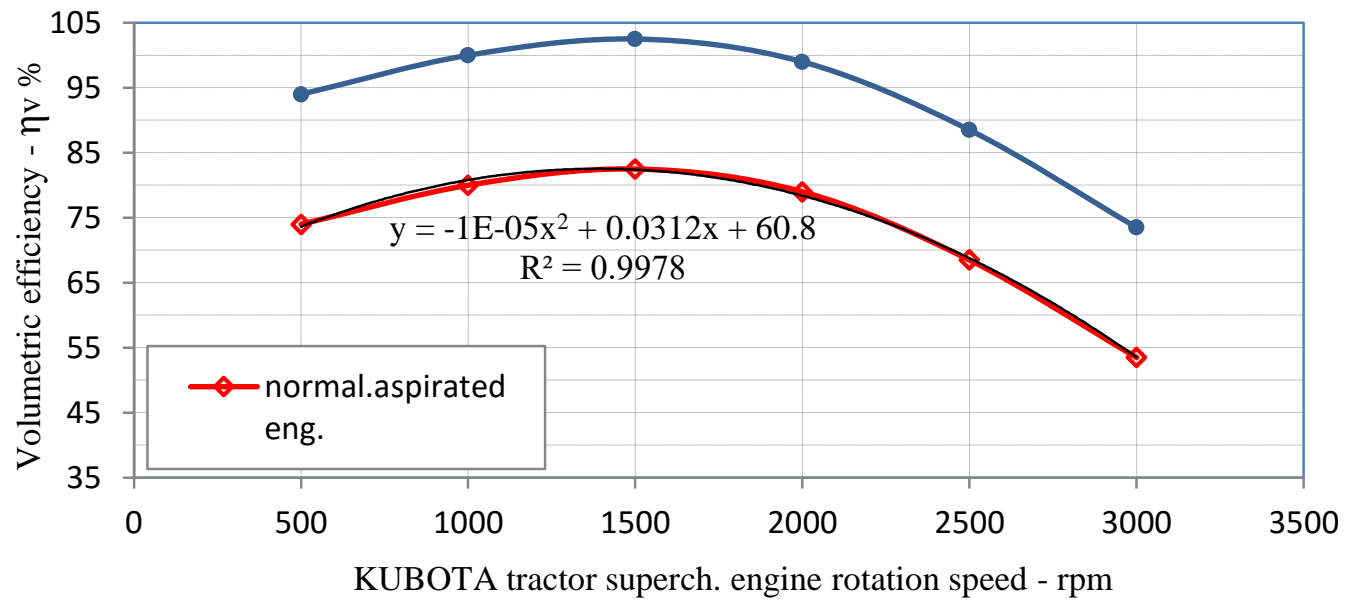

Fig.(15): adapted $\eta_{v}$ from Gupta (2009) vs. superch.eng.speed.

measured $\eta_{v}$ when using biodiesel fuels prepared from cotton seed oil, palm oil and flax oil. He commonly found that $\eta_{\mathrm{v}}$ for the different fuels decreased with the increase of engine speed due to the increase in air entering the engine cylinder with decrease suction pressure. But the rate of increasing air mass flow rate was lower than the rate of increasing engine speed, so, $\eta_{\mathrm{v}}$ decreases with the increase of engine speed. Further increase in engine speed does not increase air flow rate significantly so $\eta_{\mathrm{v}}$ decreases sharply. This sharp decrease happens due to high speed is accompanied by heating of charge in the inlet manifold and high friction flow losses which increases as the square of engine speed. At high engine speeds and loads, engine elements 
have high temperature causes air density to decrease which decreases $\eta_{\mathrm{v}}$ for all tested fuels. He also found that diesel fuel had higher $\eta_{\mathrm{v}}$ than biodiesel fuels due to higher air flow rate entering to engine cylinder.

AFR is calculated at all operating points similarly as done with all of the above indicators. Fig.(16) shows the variation of AFR with engine speed. At test beginning, the tractor engine is set at full throttle position without any load, then the dynamometer is gradually started to exert loading on PTO shaft while engine is freely running at maximum rotation speed. At "No load" conditions, AFR values reached their maximum for all tested fuels (28:1 33:1) despite the diminishing $\eta_{\mathrm{v}}$ in this stage; this can be referred to the little amount of fuel used under no load conditions; but they sharply decreased with load increase and corresponding fuel increase to reach 18:1 - 22:1. The ascended load caused more fuel consumption, and engine speed reduction to reach 2000 - $1500 \mathrm{rpm}$ where maximum BP \& BTE, minimum BSFC, are satisfied under maximum $\eta_{\mathrm{v}}$, and decreased AFR. The ascended load continuation leads to more of AFR decrease until reaching its minimum at full load conditions which almost braked engine speed due the braking effect of dynamometer loading, which in turn:

1) reduced the amount of fuel used

2) significantly reduced the air flow rate due to the sharp reduction in engine speed and the corresponding low $\eta_{\mathrm{v}}$ in this stage.

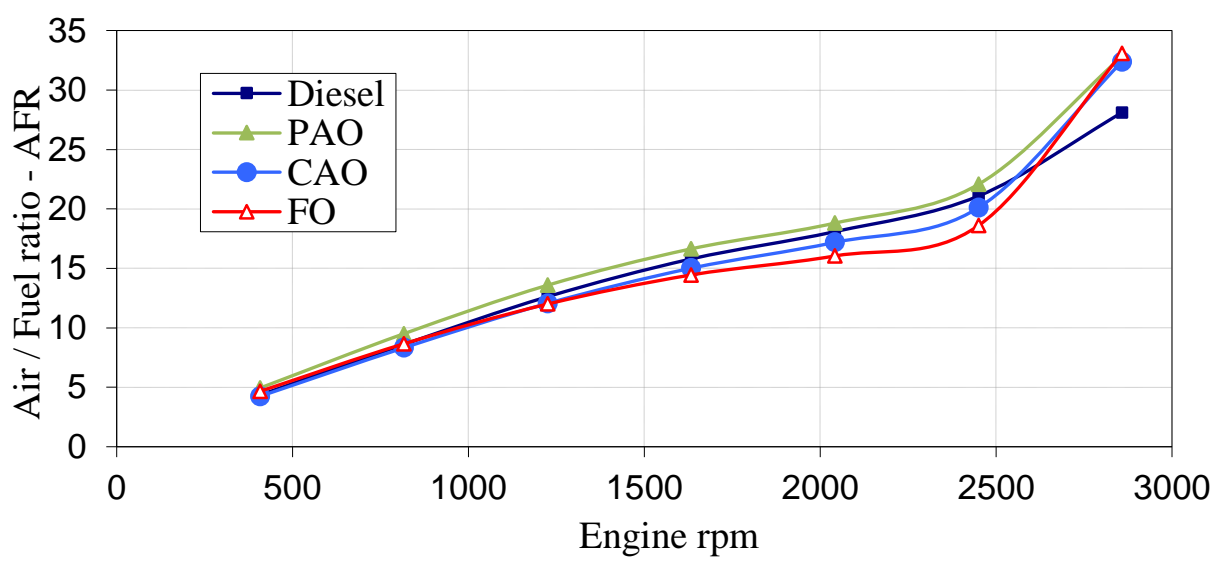

Fig.(16): Variation of AFR with engine speed .

The AFR level of the conventional diesel along the whole engine speed range wasn't the highest as it usually was in the precedent engine performance characteristics. The biodiesel from palm oil was of the highest AFR. However 
the general behavior of AFR shown in this study for all tested fuels was in good corroboration with which was described by Gupta (2009). Mohammadi et al.(2012) pointed to that poor ratio of fuel to air (which is high AFR) was more visible at higher engine speeds, and increasing torque resulted in poor AFR, which is also in good corroboration with the present study results; while Shehata (2013) presented an inverse AFR relationship to that of the present study, with engine speed where AFR decreased with increasing engine speed. This could probably be referred to accelerating the engine from idle to maximum speed under constant load, since he stated that for different fuels, as mass of fuel increases engine speed increases due to increase in heat generation. Fig.(17) shows the effect of AFR on the BMEP.

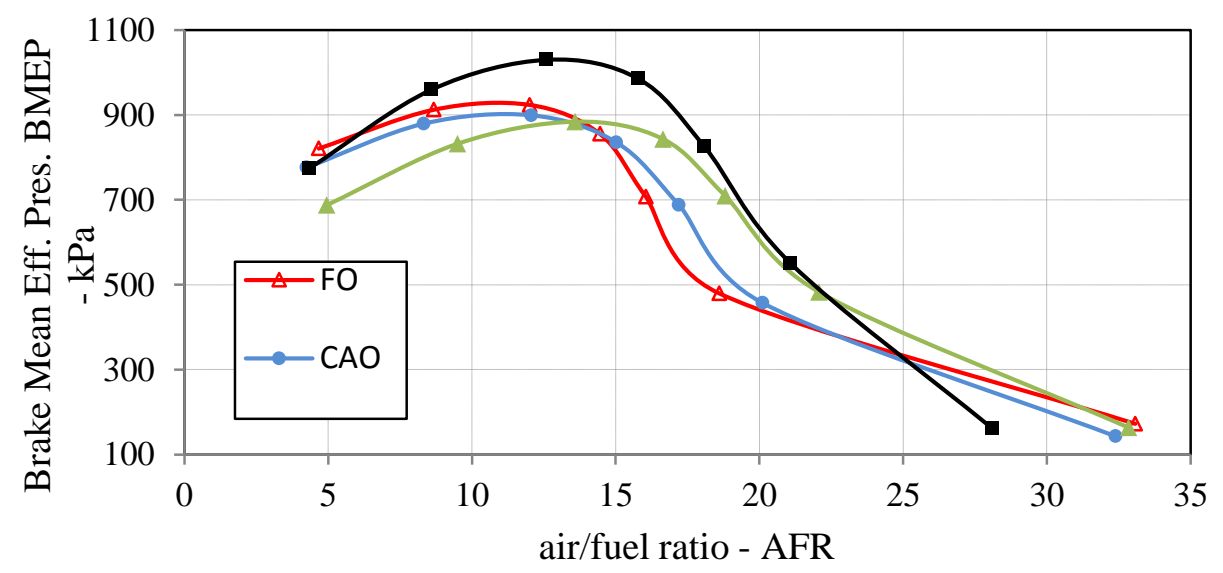

Fig.(17): Variation of BMEP with AFR

The AFR was varied from AFR $=4.25: 1$ based on mass to a very lean limit $\mathrm{AFR}=33: 1$ and engine speed varied from 400 to $2800 \mathrm{rpm}$. For all tested fuels it can be seen that the decreases of the BMEP are with increases of AFR and speed. It is obvious that the BMEP falls with a nonlinear behavior from the richest condition where AFR is 4.25:1 to the leanest condition where the AFR is 33:1. Leaving lean operating conditions $(\mathrm{BMEP}=143$ to $172 \mathrm{kPa}$ ), the engine power was decreasing from its maximum at lower speed 1000 to 1500 rpm $(\mathrm{BMEP}=834$ to $985 \mathrm{kPa})$.

\section{CONCLUSIONS}

The performance of a KUBOTA $67 \mathrm{~kW}$ tractor diesel engine has been tested with diesel fuel and three different biodiesels prepared from waste frying oil, palm oil and castor oil. The results were very comparable. Torque values 
increased for all tested fuels with the PTO or engine speed increase, until 500540 PTO rpm (around 2000 engine rpm), then they started to slightly decrease with load increase towards maximum. The highest torque values, fluctuated within $900-1000 \mathrm{Nm},(0.9-1.0 \mathrm{~kJ})$, were of conventional diesel, followed by a bundle of the three biodiesels which fluctuated around 800-900 Nm for all engine operation conditions. For all tested fuels the brake power increases with the increase of engine speed; the highest power values were obtained at 1900-2000 rpm engine speed. Diesel fuel was of the highest power (53 kW); while power levels obtained from the tested biodiesel fuels were close to each other (around $45 \mathrm{~kW}$ ). The highest brake thermal efficiency BTE values obtained at 1600 to $2000 \mathrm{rpm}$ engine speed (almost 400 to $500 \mathrm{rpm}$ PTO shaft speed) were for diesel fuel and ranged from 27.9 to $28.2 \%$. Diesel heat value was about $45 \mathrm{MJ} / \mathrm{kg}$, followed by PAO, CAO, and FO, which their heat values were $42.3,42.5$, and $42.3 \mathrm{MJ} / \mathrm{kg}$ resp. but their BTE varied from 26.776 to $26.769 \%, 23.829$ to $23.626 \%$, and 23.598 to $22.789 \%$ respectively. The brake specific fuel consumption BSFC trend for diesel and the three biodiesel fuels are similar in nature. The results also showed that the BSFC of the biodiesel fuels are higher than that of conventional diesel. This behavior is attributed to their noticeably lower heating value per unit mass, than that of the diesel fuel. The highest BMEP was of the conventional diesel fuel due to high heating value. For all tested fuels, the peak of both brake mean effective pressure and torque occurred almost at engine speed of $1200 \mathrm{rpm}$. BMEP for all fuels increases with the increase of BP to a certain engine speed. After that, BMEP is retreated at the final engine working points. At "No load" conditions, AFR values reached their maximum for all tested fuels (28:1 33:1); but they sharply decreased with load increase and corresponding fuel increase to reach 18:1 - 22:1 and engine speed reduction to reach $2000-1500$ rpm where maximum BP \& BTE, and minimum BSFC are satisfied. For all tested fuels it can be seen that the decreases of the BMEP are with increases of AFR and speed.

In general, the discussed indicators of performance always showed the superiority of conventional diesel and the resemblance of the tested biodiesels. Hence, there is no distinctive biodiesel performance which can be recommended among the three different tested fuels. So, the decision of selecting a specific biodiesel (from a specific source) depends mainly on its best economical feasibility wherever is used and the availability of the biosource. 


\section{REFERENCES}

Agarwal, D. and A. K. Agarwal, 2007 . Performance and emission characteristics of Jatropha oil (preheated and blends) in a direct injection compression ignition engine. Applied Thermal Eng. 27(13), $2314-2323$.

Baiju, B.; M.K. Naik, and L.M. Das, 2009 . A comparative evaluation of compression ignition engine characteristics using methyl and ethyl esters of Karanja oil, ,Renewable Energy 34 , 1616-1621.

Barsin, N. J.; A. L. Humke, and J. Deere, 1981. Performance and emission characteristics of a naturally aspirated diesel engine with vegetable oil fuels.SAE 810262, SAE 810955,

Behcet, R., 2011. Performance and emission study of waste anchovy fish biodiesel in a diesel engine, Fuel Processing Technology Vol 92, Iss 6, June, Pages 1187-1194

Buyukkaya, E., 2010 . "Effects of biodiesel on a DI diesel engine performance, emission and combustion characteristics", Fuel, 89, pp. 3099- 3105 .

Gupta, H.N., 2009. Fundamental of Internal Combustion Engines. , ISBN-978-81-203-2854-9

Krawczyk, T., 1996. Biodiesel Alternative fuel makes inroads but hurdles remain. INFORM 7, 801:829.

Mohammadi, P.; A. M. Nikbakht, M. Tabatabaei, and K. Farhadi, 2012 Experimental investigation of performance and emission characteristics of DI. Energy, 46, 596e605.

Otera, J., 1993. Transesterification Chem Rev;93(4):1449-70.

Reed, T. B.; M. S. Graboski, and S. Gaur, 1991 Development and commercialization of oxygenated diesel fuels from waste vegetable oils. Energy from Biomass and Wastes. 907-914.

Shahid, E. M. and J. Jamal, 2011 Production of biodiesel : a technical review. Renew Sustain Energy Rev ;15(9):4732-45.

Shehata, M.S., 2013 Emissions, performance and cylinder pressure of diesel engine fuelled by biodiesel fuel. Fuel .

Saka, S. and D. Kusdiana, 2001 Biodiesel fuel from rapeseed oil as prepared in supercritical methanol. Fuel ;80:225-31.

Staat, F. and E. Vallet, 1994. Vegetable oil methyl ester as a diesel substitute. Chem Ind, 863-856. 
Zhang, Y.; M.A. Dube, and M. Kates, 2003. Biodiesel production from waste cooking oil: Economic assessment and sensitivity analysis, Bioresour Technol, 90: 229-240.

\section{الملخص العربي}

\section{تقيم أداء محرك الديزل للجرار باستخدام وقود حيوي من ثلاثة مصادر منفردة مختلفة}

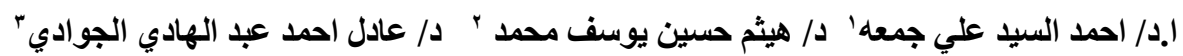

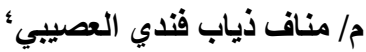

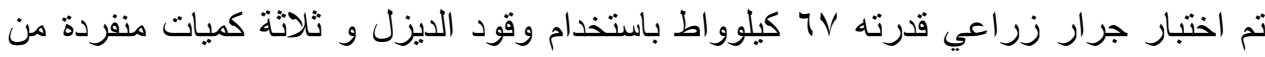

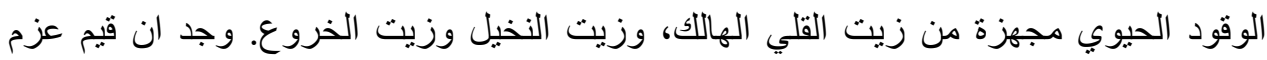

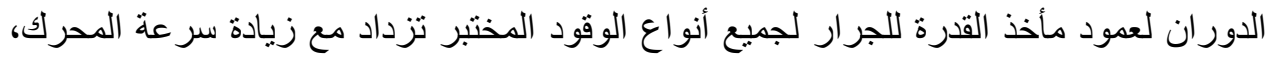

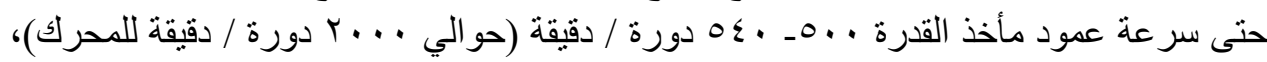

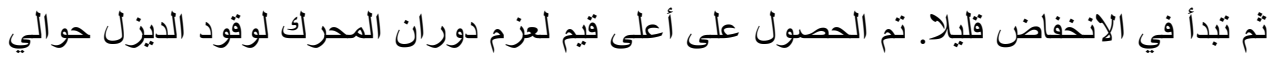

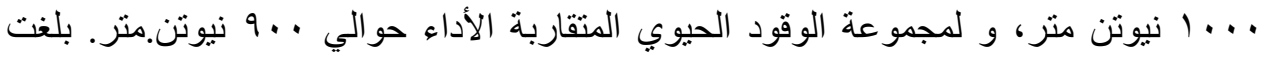

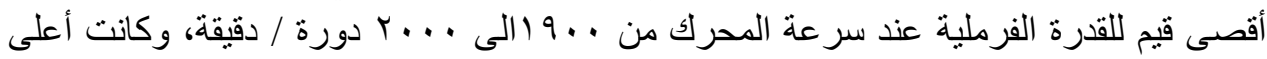

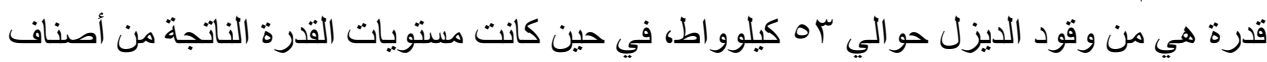

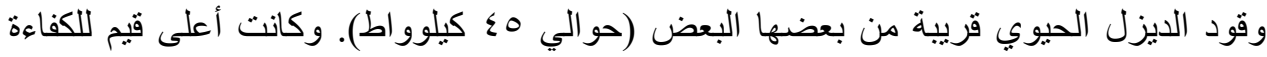

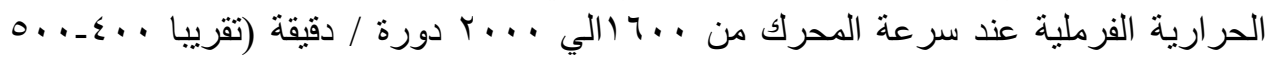

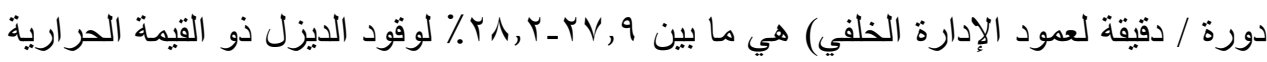

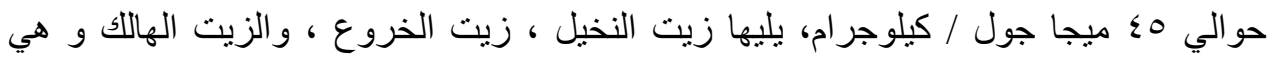

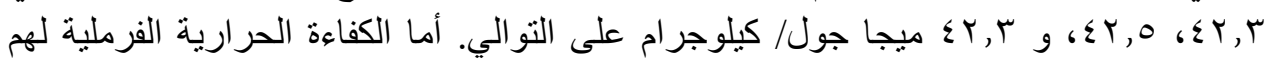
اختلفت على النحو الآتي:

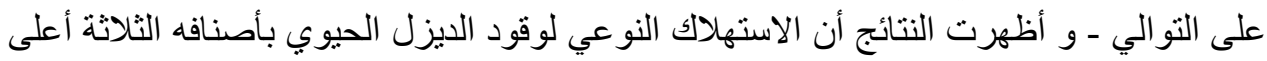

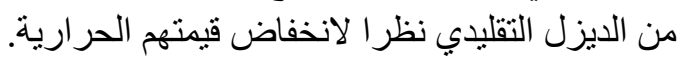

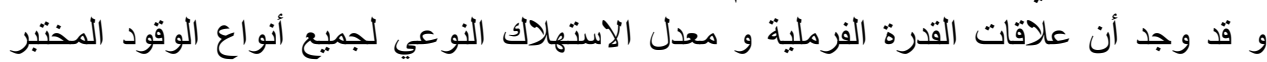

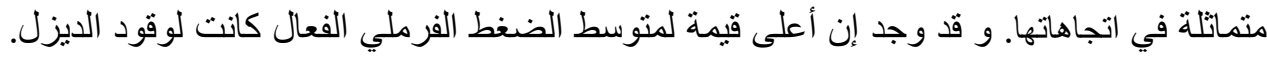

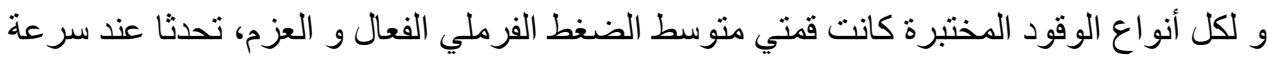

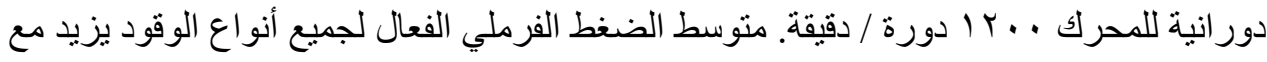

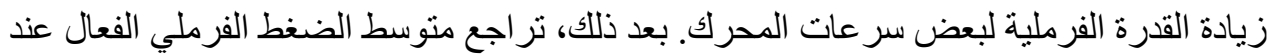

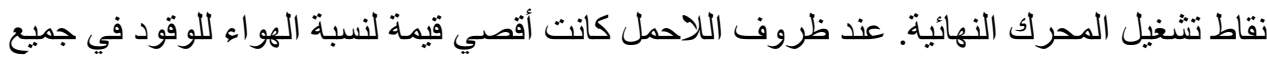

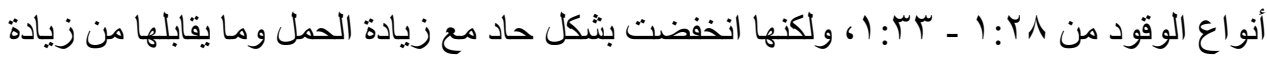

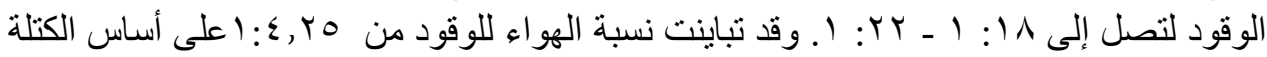

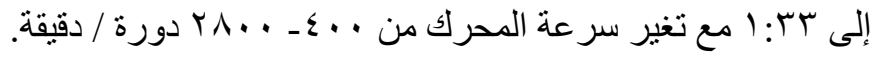

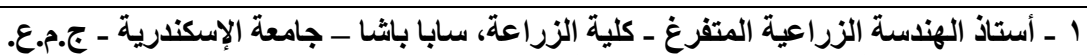

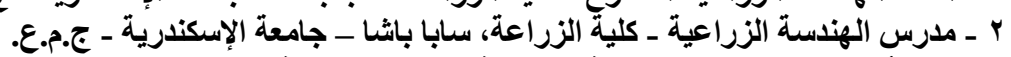

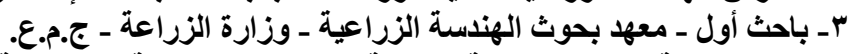

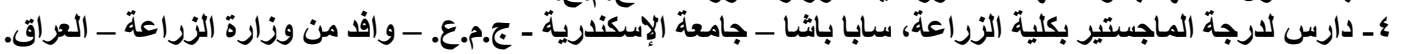

